\title{
Manifestasi Klinis dan Manajemen Keratitis Herpes Simpleks di RS. Dr. M. Djamil pada Januari 2012 - Desember 2013
}

\author{
Raihana Rustam¹, Getry Sukmawaty ${ }^{2}$, Havriza Vitresia²
}

\begin{abstract}
Abstrak
Herpes Simpleks Keratitis (HSK) merupakan salah satu penyebab kerusakan kornea. HSK terjadi akibat infeksi Herpes Simplex Virus tipe 1 (HSV-1). HSK memiliki manifestasi klinik dari epitel sampai endotel. Diagnosis didukung dengan penurunan sensibilitas kornea, pemeriksaan Giemsa dan Papaniculou. Terapi tergantung pada temuan klinis, yang bisa merupakan kontraindikasi untuk manifestasi yang berbeda. Tujuan penelitian ini adalah untuk menggambarkan variasi kasus HSK, manifestasi klinis dan managemen. Metode: Studi retrospektif dari data rekam medik bulan Januari 2012-Desember 2013, Bagian Mata, RS.M.Djamil. Pasien HSK sebanyak 52 orang, bilateral 6 orang (58 mata), wanita $50 \%$, pria $50 \%$. Pasien terbanyak pada kelompok usia $31-40$ th $(26,9 \%)$. Tipe keratitis terdiri atas Epitelial 18 mata, Stromal 22 mata, gabungan 12 mata, Keratouveitis 4 mata dan Neurotropik Keratopati 2 mata. Pemeriksaan penunjang dengan tes sensibilitas kornea, Giemsa dan Papanicolou. Terapi yang diberikan antara lain Acyclovir salep mata, Acyclovir oral, Kortikosteroid tetes mata. Perbaikan visus paling banyak pada tipe keratitis stromal, 9 mata(40,9\%) dan kombinasi, 9 mata(75\%). Loss Case banyak pada keratitis epitelial, 11 mata(61,1\%) karena pasien tidak kontrol kembali. Pemeriksaan Giemsa ditemukan Mononuclear Cell 21, Giant cell positif 12, Papanicolou positif 6 . Semua kasus didapatkan penurunan sensibilitas kornea.Terapi yang diberikan Acyclovir salep mata, Acyclovir oral, Kortikosteroid tetes. Amnion Graft Transplantation dilakukan pada 2 kasus. Kasus terbanyak ditemukan tipe stromal $22(37,9 \%)$ dengan bilateral $6(10,3 \%)$ dan perbaikan visus $(39,6 \%)$.
\end{abstract}

Kata kunci: Herpes Simpleks Keratitis, Epithelial, Stromal, Endothelitis

\begin{abstract}
Herpes simples keratitis (HSK) is a leading cause of corneal blindness worldwide. HSK result from an infection with Herpes Simplex Virus type 1 (HSV-1). Herpes Simplex Keratitis (HSK) appears with much clinical manifestation, from epithel to endohel. Diagnose supported by decrease of corneal sensibility, Giemsa staining, Papanicolou test. The treatments depend on the clinical finding, and will be contra indicated for other manifestation. The objective of this study was to describe HSK cases, Clinical Manifestation and Management. Retrospective study was obtained medical record from January 2012 to 2013 at Department of Ophthalmology, M. Djamil Hospital. Patients HSK were 52 persons, bilateral 6 (58 eyes), females 50\%, male 50\%. Patient mainly in the age group 31-40 (26,9\%). Type of keratitis consist of Epithelial 18 eyes, Stromal 22 eyes, combines forms 12 eyes, Keratouvetis 4 eyes, and Neurotropic Keratopathy 2 eyes. Ancillary test with corneal sensibility, Giemsa staining, Papanicolou. The treatment was Acyclovir ointment, Acyclovir oral, Corticosteroid eye drop. The most improvement visual acuity was stromal keratitis 9(40,9\%) and combines forms 9 (75\%). Loss case in epithelial keratitis 11 (61,1\%) cause patient didn't comeback. Giemsa staining dominant found Mononuclear Cell 21, Giant cell positive 12, Papanicolou positive 6. The all cases, decrease of corneal sensibility, Treatment given Acyclovir ointment, Acyclovir oral, Corticosteroid eye drop. Amnion Graft Transplantation have done for 2 cases. Majority cases were stromal 22 (37,9\%), bilateral 6 (10,3\%), improvement visual acuity $(39,6 \%)$.
\end{abstract}

Keywords: Herpetic Keratitis, Epithelial, Stromal, Endothelitis

Affiliasi penulis: 1. Pendidikan Dokter Spesialis Mata FK Unand (Fakultas Kedokteran Universitas Andalas) 2.Bagian IImu kesehatan Mata RSUP Dr. M. Djamil, Padang.

Korespondensi: Raihana Rustam. e-mail: ry_hana22@yahoo.co.id Telp/HP :085283001055

\section{PENDAHULUAN}

Keratitis herpes adalah penyakit infeksi terbanyak yang menyebabkan penurunan penglihatan pada negara berkembang. Diperkirakan 20.000 kasus baru okular HSV terjadi di USA setiap tahun dan lebih dari 28.000 reaktivitas terjadi setiap tahunnya. HSV merupakan salah satu yang paling sering menyebabkan kebutaan di USA dan 500.000 kasus per tahun orang mengalami infeksi HSV yg berhubungan dengan mata. Keratitis HSV adalah merupakan salah satu penyakit yang paling sering mendapatkan tranplantasi kornea di USA. ${ }^{1,2,3}$

Keratitis HSV menjadi salah satu tantangan yang harus dihadapi ahli mata. Variasi manifestasi klinisnya tidak hanya keratitis infeksi tapi juga reaksi immunologis yang dapat menimbulkan efek pada setiap lapisan kornea. ${ }^{4,5}$ Infeksi virus Herpes Simplex dapat bermanifestasi dalam berbagai bentuk, antara lain: (1) Keratitis epithelial infeksius (Cornea vesicles, Dendritic ulcer, Geographic Ulcer, and 
Marginal Ulcer), (2) Neurotropic keratopathy (punctate epithelial erosi, Neurotropic Ulcer), (3) Stromal keratitis (Necrotizing stromal keratitis, immune stromal keratitis), dan (4) Endothelitis (Disciform, Diffuse, Linear).

\section{Keratitis Epitelial}

Lesi epithelial HSV awalnya berupa lesi kecil pada epitel, yang disebut sebagai punctate epithelial keratopathy (PEK). Manifestasi umum dari kerititis HSV adalah ulkus dendritik, berasal dari kata Dendron, bahasa Yunani, yang berarti pohon. Gambaran ulkus dendritik ini bercabang, lesi linear dengan ujung yang membulat, yang mengandung virus. ${ }^{4,6}$

Ulkus dendritik yang meluas disebut dengan ulkus geografik. Sama seperti ulkus dendritik, lesi ini terdapat pada epitel yang meluas hingga membran basalis. ${ }^{6}$

Manifestasi lain keratitis epithelial HSV adalah ulkus marginal. Ujung dari lesi ini terletak pada limbus yang disertai dengan pembuluh darah. Lesi epitel ini akan secara cepat diinfiltrasi oleh sel darah putih dari pembuluh darah limbus terdekat.

\section{Neurotrophic Keratopathy}

Kelainan ini tidak berhubungan dengan imun ataupun infeksi. Ini terjadi akibat kerusakan persarafan kornea yang ditambah dengan menurunnya sekresi air mata. ${ }^{6}$

Tanda paling awal dari keratopati neurotropik adalah permukaan kornea yang tidak rata dan erosi epitel berbentuk pungtat. Erosi ini dapat berkembang menjadi Persisten Epithelial Defect dan bahkan ulkus kornea neurotropik. Komplikasinya dapat berupa sikatrik pada stroma, neovaskularisasi, nekrosis dan perforasi. ${ }^{4,6}$

\section{Keratitis stromal}

Dua bentuk kelainan yang melibatkan stromal secara primer adalah keratitis stromal secara primer adalah keratitis stromal nekrotik dan Immune Stromal Keratitis (ISK). ${ }^{4,6}$ Keratitis stromal nekrotik ditandai dengan infiltrat stromal padat, ulserasi dan nekrosis yang diyakini sebagai hasil dari replikasi virus pada stromal keratocytdan karena respon inflamasi dari tubuh. Immune Stromal Keratitis (ISK/Keratitis stromal non nekrotik atau keratitis intertisial) merupakan manifetasi okular HSV yang paling sering dalam bentuk kronis rekuren. Komplemen anti bodi yang meningkat untuk menahan antigen virus dalam stroma diyakini sebagai mekanisme dasar terjadinya kelainan.

\section{Endotelitis}

Gejala klinis dari endotelitis diantaranya bisa timbul keratic precipitates (KP), edema stromal dan epitel. Iritis yang ringan sampai sedang sering terlihat pada kelainan ini. Reaksi immunologi untuk antigen virus dalam endotel kornea merupakan patogenesis dasar terjadinya kelainan ini, namun replikasi virus dapat diklasifikasikan dengan bentuknya yang disciform, difus dan linear.

\section{Herpes Simplex Keratouveitis}

Herpes simplex keratouveitis muncul sebagai uveitis dengan jenis keratitis berbagai derajat, mulai dari ringan sampai berat. Reaksi seluler yang signifikan pada COA merupakan kriteria yang harus ditemukan pada herpes simplex keratouveitis. Uveitis ini muncul dengan "mutton fat" keratic precipitate di endothelium. Penyembuhan alami pada herpes simplex keratouveitis minimal terjadi dalam 2-6 bulan, dan dampak terhadap visus bergantung pada berat dan durasi inflamasi. ${ }^{4,7}$

Pada $75 \%$ pasien, diagnosis keratitis HSV dapat ditegakkan berdasarkan gambaran klinis khas berupa defek di kornea dan penurunan sensibilitas kornea. Hanya dalam keadaan yang maragukan, pemeriksaan laboratorium dapat membantu untuk mengkonfirmasikan dugaan klinis pada kasus dengan gambaran klinis tidak khas. ${ }^{8,9}$

Kerokan epitel dengan pewarnaan Giemsa dan Papanicolaou dapat ditemukan Eosinophilic intra nuclear inclusion bodies, multinucleated giant cell hasil dari penggabungan sel epitel kornea yang terinfeksi dan inklusi virus intra nuklear, namun hasil pemeriksaan yang negatif tidak menyingkirkan kemungkinan infeksi HSV.

- Kultur virus adalah pemeriksaan laboratorium "Gold Standar" dan sangat sensitif terutama pada lesi baru. Hasil kultur virus dapat membedakan sub tipe HSV (HSV-1 atau HSV-2).

- Polimerase Chain Reaction (PCR) menggunakan sampel air mata, epitel kornea, tap kamera okuli anterior yang dapat mendeteksi DNA virus pada kasus keratitis herpes atau keratouveitis. Namun pemeriksaan ini tidak dapat membedakan antara infeksi laten atau aktif.

Infeksi HSV okuler primer merupakan selflimited disease. Terapi antiviral sistematik dapat mempercepat resolusi gejala yang muncul. ${ }^{1}$

Trifluridine $1 \%$ topikal, 8 kali sehari, dapat diberikan pada keratitis epitelial dendritik dan geografik. Pengobatan anti viral topikal secara umum dilanjutkan selama 10-14 hari untuk mencegah toksisitas terhadap permukaan okular. Acyclovir salf 3 $\%$ lebih efektif dan memiliki toksisitas yang lebih rendah dari pada Trifluridine dan Vidarabine. Acyclovir oral memiliki efektivitas yang sama dengan antiviral topikal dalam mengobati keratitis epitelial, dan tidak toksik terhadap okuler. Dengan alasan inilah, terapi oral lebih dipilih oleh para ahli. Kortikosteroid topikal kontraindikasi, pada keratitis herpes epitelial yang aktif. Oleh karenanya, pasien dengan pengobatan kortikosteroid sistemik untuk indikasi yang lain, harus diterapi lebih agresif dengan antiviral sistemik. 1,6,7 Banyak kontroversi mengenai penatalaksanaan HSV keratitis stroma. Temuan HEDS menunjukan bahwa kortikosteroid topikal yang diberikan bersamaan dengan antiviral profilaks dapat mengurangi progresifitas inflamasi stroma dan mempersingkat durasi HSV keratitis stroma. 8,9,10

Sediaan antiviral topikal tidak diserap oleh kornea melalui epitel yang intak, tapi Acyclovir oral dapat berpenetrasi pada kornea dan COA. Oleh karena itu, Acyclovir oral memiliki keuntungan untuk inflamasi kornea yang dalam pada keratitis disciformis. ${ }^{1}$ Toksisitas antiviral topikal tidak diharapkan pada pasien dengan necrotizing herpetic karena dapat mengaburkan gambaran klinis. Oleh karena itu, antiviral oral seperti Acyclovir lebih dipilih. Untungnya, keratitis herpetic necrotizing sangat sensitif terhadap kortikosteroid topikal, dan pemberian 2 kali sehari dapat mengontrol inflamasi pada banyak pasien. ${ }^{1}$

Keratitis stromal dan endotelitis diterapi dengan kombinasi anti virus dan kortikosteroid. Anti virus lebih sering diberikan pada awalnya, selanjutnya dinilai berdasarkan respon klinis, jika responnya baik, 
kortikosteroid diberikan untuk mengontrol proses inflamasi dan kemudian dosis steroid diturunkan sampai dosis terkecil. Alternatif lain, acyclovir oral dengan dosis menengah $5 \times 200,400 \mathrm{mg} \mathrm{(1-2} \mathrm{gr/hari}$ ) akan dapat mencapai konsentrasi terapeutik dalam akuos humor dan lebih efektif dari pada terapi topikal dalam pengobatan keratouveitis HSV. ${ }^{1,2}$

Pembedahan biasanya dilakukan pada pasien dengan keratitis herpes berulang dan atau pada pasien dengan jaringan parut untuk tujuan memperbaiki visual. Namun, operasi juga diperlukan sebagai tindakan terapeutik pada pasien dengan ulkus tanpa perbaikan atau impending perforasi pada keratitis nekrotik. ${ }^{10,11}$ Tindakan transplantasi kornea sebaiknya ditunggu minimal selama 6 bulan setelah infeksi HSV untuk meningkatkan angka keberhasilan. Acyclovir profilaks dimulai sebelum operasi dan dilanjutkan selama minimal 6 bulan untuk mengurangi risiko kegagalan. ${ }^{10,11,12}$ Teknik flap konjungtiva berguna pada pasien dengan keratitis kronis yang mungkin telah menjadi ulkus kornea dengan impending perforasi. ${ }^{10}$ Memberikan amnion telah terbukti mengurangi inflamasi dan membantu penyembuhan ulkus neurotropik pada keratitis HSV. ${ }^{10,12}$

\section{METODE}

Penelitian dilakukan di poliklinik dan bangsal mata RSUP DR. M. DJAMIL Padang. Waktu penelitian bulan januari 2012 - Desember 2013.

Penelitian ini merupakan penelitian retrospektif dimana data dikumpulkan dari pasien baru yang terinfeksi virus herpes simplex pada mata, yang datang ke poliklinik mata RS. DR. M. Djamil Padang serta di follow up kondisi terakhir pasien setelah pemberian obat dari bulan januari 2012 sampai dengan Desember 2013.

Pasien yang berkunjung ke poliklinik mata yang sudah ditetapkan oleh sub bagian infeksi imunologi sebagai penderita infeksi HSV pada mata dengan kriteria:

Terdapat defek pada kornea.

Pemeriksaan penunjang laboratorium

pewarnaan Giemsa MN > PMN.

Sensibilitas kornea yang menurun.

\section{HASIL PENELITIAN}

Tabel 1. Distribusi penderita herpes simplek mata berdasarkan jenis kelamin dan kelompok umur

\begin{tabular}{|c|c|c|c|}
\hline Kelompok & \multicolumn{2}{|c|}{ Jenis Kelamin } & Total \\
\hline Umur & Laki-laki & Wanita & \\
\hline$<10$ th & 1 & 1 & $2(3,8 \%)$ \\
\hline $10-20$ th & 4 & 4 & $8(15,3 \%)$ \\
\hline $21-30$ th & 5 & 3 & $8(15,3 \%)$ \\
\hline $31-40$ th & 10 & 4 & $14(26,9 \%)$ \\
\hline $41-50 \mathrm{~h}$ & 4 & 7 & $11(21,3 \%)$ \\
\hline$>50$ th & 2 & 7 & $9(17,4 \%)$ \\
\hline Total & $26(50 \%)$ & $26(50 \%)$ & $52(100 \%)$ \\
\hline
\end{tabular}

Tabel 2. Distribusi penderita herpes simplek mata berdasarkan diagnosa

\begin{tabular}{lc}
\hline \multicolumn{1}{c}{ Diagnosis } & $\mathbf{N}(\%)$ \\
\hline Keratitis Epitelial & $18(31 \%)$ \\
Keratitis Stromal & $22(37,9 \%)$ \\
Endotelitis & 0 \\
Keratitis yang mengenai $\geq 2$ & $12(20,7 \%)$ \\
lapisan kornea & \\
Keratouveitis & $4(6,9 \%)$ \\
Neurotropik Keratopati & $2(3,5 \%)$ \\
\hline
\end{tabular}

\begin{tabular}{lc}
\hline \multicolumn{1}{c}{ Total } & $\mathbf{5 8 ~ ( 1 0 0 \% )}$ \\
\hline Catt : Jumlah pasien 52 orang, bilateral 6 orang. \\
Tabel 3. Distribusi penderita herpes simplex mata \\
berdasarkan pemeriksaan laboratorium Giemsa \\
dan Papanicolou \\
\hline Pemeriksaan Penunjang & Frekuensi \\
\hline $\begin{array}{l}\text { Sensibilitas Kornea } \\
\text { Penurunan Sensibilitas Kornea }\end{array}$ & 58 \\
$\begin{array}{l}\text { Giemsa } \\
\text { Sel MN dominan }\end{array}$ & 21 \\
Sel MN dominan + Giants Cell & 12 \\
Papanicolou & 6 \\
Virus Positif & \\
\hline
\end{tabular}

Ket : Sel MN = Sel Mononuklear

Tabel 4. Distribusi penderita herpes simplek mata berdasarkan terapi yang diberikan.

\begin{tabular}{|l|c|c|c|c|c|c|}
\hline \multicolumn{1}{|c}{ Diagnosis } & $\begin{array}{c}\text { Acyclovir } \\
\text { Topikal }\end{array}$ & $(\%)$ & $\begin{array}{c}\text { Acyclovir } \\
\text { Sistemik }\end{array}$ & $(\%)$ & $\begin{array}{c}\text { KS } \\
\text { Topikal }\end{array}$ & $(\%)$ \\
\hline Keratitis Epitelial & 18 & 100 & 6 & 33,3 & 0 & 0 \\
\hline Keratitis Stromal & 17 & 77,3 & 22 & 100 & 15 & 68,1 \\
\hline $\begin{array}{l}\text { Keratitis yang mengenai } 2 \\
\text { 2 lapisan kornea }\end{array}$ & 7 & 58,3 & 12 & 100 & 8 & 66,6 \\
\hline Keratouveitis & 0 & 0 & 4 & 100 & 4 & 100 \\
\hline Neurotropik Keratopati & 2 & 100 & 2 & 100 & 0 & 0 \\
\hline
\end{tabular}

Ket : KS : kortikosteroid

NB : Pada 2 kasus Neurotropik Keratopati dilakukan tindakan Amnion Membrane Transplantation.

Tabel 5. Perubahan visus penderita herpes simpleks mata setelah follow up berdasarkan visus kondisi terakhir.

\begin{tabular}{lc}
\hline \multicolumn{1}{c}{ Perubahan Visus } & $\mathbf{N}(\%)$ \\
\hline Membaik & $23(39,6 \%)$ \\
Menetap & $15(25,8 \%)$ \\
Memburuk & $6(10,3 \%)$ \\
Loss Case & $14(24,1 \%)$ \\
Total & $\mathbf{5 8 ( 1 0 0 \% )}$ \\
\hline
\end{tabular}

\section{PEMBAHASAN}

Dari hasil penelitian yang dilakukan selama 2 tahun di poliklinik mata RS.Dr.M.Djamil Padang dari bulan Januari 2012- Desember 2013 didapatkan 52 mata yang didiagnosis sebagai keratitis herpes simpleks. Diagnosis ditegakkan berdasarkan adanya gejala klinis seperti adanya infiltrat pada kornea, sensibilitas kornea yang menurun, ditambah dengan pemeriksaan penunjang laboratorium pewarnaan Giemsa dan Papanicolou. Pada penelitian ini, didapatkan kelompok umur 31-40 tahun merupakan kelompok umur terbanyak yang datang ke poliklinik mata dengan infeksi HSV yaitu 14 orang $(26,9 \%)$, hal ini sesuai dengan kepustakaan yang mengatakan bahwa studi epidemiologi menemukan sebagian besar penderita HSV sering mengenai usia pertengahan. Penelitian yang dilakukan oleh Raju dkk pada Departement Ophthalmology of Calicut Medical College dari Januari 2008-Juni 2009, didapatkan jumlah penderita wanita lebih banyak $5 \%$ dari pada laki-laki, dengan kelompok umur 40-50 tahun (26,7\%) diikuti oleh kelompok umur 20-40 tahun (20\%). Dari literatur dikatakan bahwa virus Herpes Simpleks ditransmisikan melalui kontak dengan sekret lesi terinfeksi yang dipengaruhi oleh umur dan aktivitas dalam penyebarannya. Disebutkan juga bahwa populasi yang terinfeksi herpes simpleks di negara 
berkembang banyak mengenai masyarakat golongan sosial ekonomi rendah, $70-80 \%$ pada dewasa muda. ${ }^{1,5}$

Pada penelitian ini diagnosa yang paling banyak ditemukan adalah keratitis stromal yaitu 22 mata $(37,9 \%)$, diikuti keratitis epitelail 18 mata $(31 \%)$, keratitis yang mengenai $\geq 2$ lapisan kornea 11 mata $(18,9 \%)$ dan keratouveitis 4 mata $(6,8 \%)$. Dari penelitian Raju dkk, dari total 45 pasien didapatkan keratitis epitelial $53,4 \%$, keratitis stromal $26,7 \%$ dan endotelitis $17,8 \% .^{5}$ Dilihat dari perjalanan penyakit yang timbul, dimana pada awalnya muncul kelainan pada daerah epitel yang apabila tidak diterapi secara cepat akan menimbulkan kelainan yang lebih dalam dari lapisan kornea atau timbul komplikasi lain akibat penanganan yang terlambat atau terapi yang tidak tepat. Infeksi herpes simpleks primer seringkali asimptomatis ( $>90 \%$ kasus). Banyak pasien terdeteksi memiliki serum antibodi HSV yang diperoleh dari sekret tubuh tanpa ada riwayat infeksi herpes sebelumnya.

Dalam menegakkan diagnosis keratitis herpes simpleks dapat dibantu dengan beberapa pemeriksaan penunjang. Sensibilitas kornea yang menurun ditemukan pada seluruh pasien penelitian ini. Sel MN dominan terdapat pada $36,8 \%$, Giant Cell positif ditemukan 21\%, serta pemeriksaan Papanicolou ditemukan positif infeksi virus pada $10,5 \%$ kasus. Saat ini dipakai beberapa teknik pemeriksaan lain dalam mendeteksi infeksi virus herpes simpleks. Immunoflourescence Assay (IFA) dapat mendeteksi antigen HSV-1, Polymerase Chain Reaction (PCR) mendeteksi DNA HSV-1 dan kultur virus. Penelitian yang dilakukan oleh Badawy dan Soltan di Mansoura University tahun 2008, didapatkan bahwa PCR memiliki sensitivitas yang lebih tinggi $(100 \%)$ dibandingkan IFA $(70 \%)$. Oleh karena itu, kombinasi IFA dan PCR lebih dipilih dalam menegakkan diagnosis pasien suspek keratitis herpes simpleks dengan ditemukannya Multinucleated Giant Cell pada pewarnaan Giemsa. ${ }^{8}$

Keratitis herpes epitelial merupakan self limited disease, namun beberapa ahli mencoba menggunakan pengobatan antiviral topikal dan oral seperti Acyclovir, dan secara signifikan meningkatkan hasil pengobatan, dengan meminimalkan kerusakan stroma dan timbulnya jaringan parut. Terapi yang paling banyak diberikan adalah Antiviral Acyclovir, banyak dipakai karena Acyclovir mempunyai efek toksik yang lebih rendah dari pada jenis antiviral lainnya. Debridemant jaringan epitel yang terinfeksi dapat dilakukan dengan steril cotton tip applicator secara gentle dan hati-hati untuk menghindari kerusakan membran basalis serta mencegah perluasan sel epitel yang terinfeksi ke jaringan yang masih sehat. Selain itu dengan membuang jaringan yang terinfeksi dapat mengurangi jumlah antigen virus yang berada pada stroma. Bila epitelisasi belum terbentuk, hati-hati pemberian kortikosteroid topikal. ${ }^{9}$

$$
\text { Penggunaan kortikosteroid topikal }
$$
memberikan keuntungan pada keratitis stromal. Tujuan pemberian kortikosteroid topikal adalah untuk mencegah infiltrasi seluler, opasifikasi dan sikatrik, menghambat neovaskularisasi dan mencegah pengeluaran enzim toksik. Namun, juga harus dipertimbangkan komplikasi yang mungkin timbul akibat kortikosteroid topikal, terutama efek ketergantungan steroid dan inflammatory rebound Oleh karena itu, jika memungkinkan, pemberian kortikosteroid topikal dapat ditunda pada kasus inflamasi stroma ringan atau bukan di visual axis. Pasien keratouvetis diterapi dengan Acyclovir oral 400 $\mathrm{mg}, 5 \times$ sehari selama 10 minggu, dan kortikosteroid topikal. Setelah diberikan terapi dan dilakukan follow up pada pasien, berdasarkan pada visus kondisi terakhir ditentukan perbaikan terjadi sebanyak $39,6 \%$ kasus, menetap sebanyak $25,8 \%$, perburukan $10,3 \%$ dan loss case didapatkan sebanyak $24,1 \%$ karena pasien tidak datang lagi ke poliklinik. Terapi surigikal dilakukan terhadap 2 pasien yaitu dengan Amniotic Membrane Transplantation (AMT). Tindakan ini dipilih karena sesuai literatur, amniotic membrane mampu mengurangi inflamasi dan membantu penyembuhan keratitis HSV dengan cara mengurangi jumlah sel inflamasi pada kornea. Penelitian yang dilakukan terhadap hewan percobaan dengan keratitis herpes , dilakukan transplantasi membran amnion (AMT), didapatkan hasil bahwa AMT dapat mereduksi limfosit $T$ dan menginduksi apoptosis limfosit pada kornea sehingga ditemukan penurunan yang signifikan dari sel-sel inflamasi. ${ }^{12}$

\section{DAFTAR PUSTAKA}

1. Skuta GL, Cantor LB, Weiss JS. Infectious Diseases of External Eye: Basic Consepts and Viral Infections. In: American Academy of Ophthalmology. External Disease and Cornea. San Fransisco: American Academy of Ophthairnology; 2017. 205-239

2. Serangi PP, Rouse BT. Herpetic keratitis. In: Levin LA, Albert DM. Ocular Disease, Mechanisme and Management. Philadelphia: Saunders; 2010. 91-97

3. Shtein RM, Garcia DD, Musch DC, Elner VM. Herpes Simplex Virus Keratitis Histopathologic inflamation and Corneal Allograft Rejection. Ophthalmology. 2009; 116(7):1301-1305

4. Hamrah $P$, Sahin A, Dastjerdi MH, Shahatit BM, Bayhan HA, Dana R, et al. Celluler Changes of the Corneal Epithelial and Stroma in Herpes Simplex Keratits. An In Vivo Confocal Microscopy Study. Ophthalmology. 2012;119(9): 1791-1797

5. Raju MS, Jyothi PT, Shirma I. Cilinical Profile of Herpes Simplex Keratitis. Regional institude of Ophthalmology Medical College, Calicut, Kerala Journal of Ophthalmology . 2011; 23(1):33-37

6. Farooq AV, Shukla D. Herpes simplex epithelial and stromal keratitis: an epidemiologic update. Surv Ophthalmol. 2012;57(5):448-462

7. McGilligan VE, Moore JE, Tallouzi M, Atkinson SD, O'Neill H, Feeney S, et al. A Comparison of The Clinical And Molecular Diagnosis of Herpes Simplex Keratitis. Open J

Ophthalmol. 2014;4(3):65-74

8. Satpathy G, Mishra AK, Tandon R, Sharma MK, Sharma A, Nayak N, et al. Evaluation of Tear Samples for Herpes Simplex Virus 1 (HSV) Detection in Suspected Cases of Viral Keratitis Using PCR Assay and Conventional Laboratory Diagnostic Tools. Br J

Ophthalmol. 2011;95(3):415-418

9. Sauerbrei A, Deinhardt S, Zell R, Wutzler P Testing of herpes simplex virus for resistance to antiviral drugs. Virulence. 2010;1(6):555-557

10. Hill GM, Ku ES, Dwarakanathan S. Herpes simplex keratitis. Dis Mon. 2014;60(6):239-246.

11. Gallar J, Tervo TM, Neira W. Selective changes in human corneal sensation associated with 
herpes simplex virus keratitis. Invest Ophthalmol Vis Sci. 2010;51(9):4516-4522

12. Murgova S, Balabanov C, Oblashka M. Amniotic Membrane Transplantation for Keratitis. Journal of IMAB. 2015; 21(2):784-7 